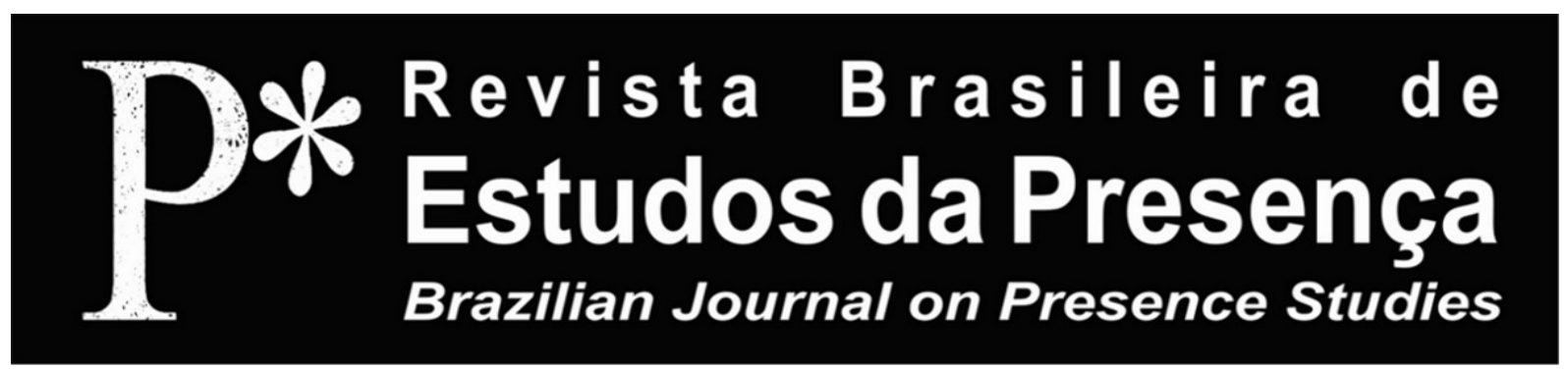

E-ISSN 2237-2660

\title{
Reconsidering Acting: a few improvised and provisory thoughts on acting today
}

Patrice Pavis University of Kent, Canterbury - United Kingdom

\begin{abstract}
Reconsidering Acting: a few improvised and provisory thoughts on acting today - This paper summarizes my thoughts during the presentation of the conference Acting reconsidered. The study of the actor in contemporary performances should be reevaluated in the light of the experiments of the last fifty years, particularly performance art, post-dramatic theatre, participative theatre and many political theatre. The new tasks and conceptions of the actor are introduced. Stanislavki's notion of psychological realism is questioned. The suggestion of de-dramatizing, delocalizing, de-training the actor might help the actor to orient oneself in the world.
\end{abstract}

Keywords: Acting. Staging. Actor's Training. Post-dramatic. Theatre.

RÉSUMÉ - Revoir le Jeu de l'Acteur: quelques remarques improvisées et provisoires sur le jeu de l'acteur aujourd'hui - Cet article résume mes idées présentées pendant la conférence intitulée Acting Reconsidered. L'étude de l'acteur dans les spectacles contemporains devrait être réévaluée à la lumière des expériences de ces cinquante dernières années, notamment le perfomance art, le théâtre postdramatique et les expériences du théâtre de participation et des nouvelles formes de théâtre politique. Il s'agit de présenter les tâches et les conceptions nouvelles de l'acteur. En particulier, d'aller au-delà de la conception du réalisme psychologique d'inspiration stanislavskienne. On propose donc de dédramatiser l'acteur, de le délocaliser, de le vider plus que de l'emplir, de le dés-entraîner, bref d'aider le spectateur à mieux s'orienter dans le monde.

Mots-clés: Interprétation. Mise en Scène. Entraînement de l'Acteur. Postdramatique. Théâtre.

RESUMO - Para Repensar o Trabalho do Ator: algumas consideraçóes improvisadas e provisórias sobre a atuaçáo hoje - Este artigo retoma algumas ideias apresentadas durante a conferência Acting Reconsidered. O estudo do ator em performances contemporâneas deveria ser reavaliado à luz de experiências dos últimos cinquenta anos, particularmente a arte da performance, o teatro pós-dramático, o teatro interativo e muitos teatros políticos. Apresentam-se novas tarefas e concepçóes de ator. Questiona-se a noção de realismo psicológico de Stanislavski. A sugestão de desdramatizar, deslocalizar, destreinar o ator pode ajudá-lo a orientar-se no mundo.

Palavras-chave: Atuação. Encenação. Treinamento do Ator. Pós-dramático. Teatro.

Patrice Pavis - Reconsidering Acting: a few 
One cannot speak in general about acting or about the actor ${ }^{1}$. My sole aim here is to provide an overview of current issues, with only a few hints at new fields of research. Has the identity and the function of the actor changed recently, and how? What are the main factors of change? What should we study? What kinds of performance, for instance?

For playwrights: the acting gives your text its final meaning. It is not a neutral instrument; it controls and determines everything. As soon as it is performed, or even read by another person, the text escapes its author.

\section{The Actor: new tasks, new conceptions}

1) The theatre, in its aesthetics, goals, has changed. The actor no longer has to do the "work of the actor on oneself" (Stanislavski). Theatre (often) has moved away from the idea of a role conceived psychologically and mimetically. The actor does not always have to imitate, or even to represent, a character. We are no longer in an aesthetic of pure imitation. The actor sets her own conventions: for example to show social mechanisms (Brecht), to focus on only one aspect, or one object, to allow another type of identification.

2) From actor to performer: being a performer means: a) to be oneself, instead of playing a role; b) to present instead of representing; to be able to perform different technical tasks: singing, dancing, fencing etc.

3) The actor must always be considered within the performance/ mise en scène, and also in tune with a changing society, i.e. with a changing audience.

4) The contemporary actor is more and more involved in the process of directing, staging, even devising the whole performance (in the so-called devised theatre). Thus the boundaries between actor, director, playwright, set designer are blurred.

For playwrights: if you don't know what your actor should be doing, ask yourself how it could help the understanding of the situation and general direction. Use the gliding scale of abstract/concrete. Think geometrically. Use the actor as a way to relativize your text, finish it, test it. Go back to writing after this probing.

5) The status of the actor within the dramaturgy also changes: the actor no longer says the text as a role, from her point of view, 
but she sometimes acts as a narrator. The traditional categories of imitating (mimesis) and telling (diegesis) are challenged. Acting and telling merge in an instance which can be both actor and narrator (sometimes called narractor). The performer thus oscillates between a dramatic actor and an epic storyteller.

6) Even when not called devised theatre, playwright and director sometimes tend to become one and the same person (for instance, the French director Joël Pommerat). The actors no longer follow the instructions of a director as in Regietheater (Director's theatre). There is a constant back and forth between writing and staging, between inventing a situation for actors and putting words upon them, and vice-versa. Actors can be the source of speech (through their improvisations) and become later the interpreter of the dramatic text of the playwright.

For playwrights: the actor does not only fulfil a limited task, she is also a part of the creative process. Here in this workshop, you can use the actors while writing and you can change your text after their performance, thus you can re-write, i.e. re-act, re-stage. It obviously depends on the acting style and genre, but generally the acting should remain open, ambiguous, not telling everything. An exercise consists in writing a short text after a non-verbal improvisation.

\section{The Actor and the Spectator: new relationships, new views}

1) In today's performance, we experience the actor in different ways, much richer than before. Actors are no longer only interpreters, readers of the text; they have often become responsible for a new experience of the spectator, for new ways of looking at a text, of producing different interpretations, or simply enjoy theatre in another way.

For instance, in immersive theatre or in one-to-one performance: the actor speaks in her name, asks personal questions, answers questions from the spectator (as herself or as an imaginary persona). The idea is no longer to deliver a message or a text, to characterize a person, but to create a new, unexpected experience for the spectator. The play-text is just a pretext for a personal experience; theatre becomes a therapy, instead of an aesthetic experience.

Other experiences with acting styles include the non-acting style: performers talk about themselves, their own personal life; gra- 
dually they become the characters (e.g. the groups L'avantage du doute or Tg STAN). In Korsunovas' Seagull's (Vilnius, October 2015) the actors first give the impression they speak to us directly and are like us, spectators. They are trying to deny that they are in fact acting. One could define acting as something that one can make fun of: for instance, when Nina speaks Treplev's monologue, in Korsunovas' production. Acting is always the parody of something. The question for the actor, and yet before for the playwright as well, is what is being parodied, or alluded to.

2) Theatre spectators and theorists have learned a lot from dance, for instance: Kinaesthetic empathy. We experience the actor differently, not only psychologically by identification or by distance (alienation effect), but as a moving body. The theory of kinaesthetic empathy tells us that watching a movement is like making the same movement.

For playwrights: before, or even better, instead of telling the actors what the characters mean, make these characters first dance within yourself, see how it feels kinaesthetically. Draw the figure, the trajectory of the actor in a scene, as a first possible blocking. Let them dance the text (which does not mean dance on the text or music).

The approach of kinaesthetic empathy must be combined with the way we perceive affects in the characters/performers and we ourselves experience these affects with an affective empathy:

Kinaesthetic empathy is linked to the affect rather than to the emotion. This means that kinaesthetic empathy can be considered as embodied intensity which has an impact on the spectator in a kinaesthetic manner. [...] Linking kinaesthetic empathy with affect rather than emotion means that it can be viewed as embodied intensity that impacts the spectator kinaesthetically (Reynolds, 2012, p. 132).

We perceive the tactility of the actor and of the stage in general: the actor and the stage are like play dough (pâte à modeler), a texture. As Bachelard (1948, p. 54) puts it: "[...] in the imagination of everyone, there exists an ideal dough, a perfect synthesis of resistance and suppleness, a marvellous balance of forces which accept and refuse". The actor's body can be prepared and later felt by the viewer as play dough, which we can touch and mix with our eyes. The actor is always more or less apprehended through a tactile, haptic perception. 
3) This kinaesthetic empathy can be felt in and as a process of embodiment. Embodiment is not the incarnation of the actor in their role (as we are asked to believe too naively). Embodiment, according to Judith Butler's feminist theory (2006), is the actor's body or our own body as a result of a fabrication, of a putting into place of conventions, repetitions, body techniques, which will make the body expressive and effective, and later ready to produce and receive affects. This means that the spectator is able to integrate movement (kinesis) into the whole performance at every moment.

The embodiment is also an "incorporation", an Einverleibung (Freud's term), which is "[...] a mode of relationship to the object which tends to make it penetrate in ourselves, stay in ourselves, at least in form of a fantasy" (Chemama; Vandermersch, 1998, p. 191) ${ }^{2}$.

Thus the actor's and the spectator's task is to incorporate, while using their kinaesthetic empathy, the actor's work, i.e. to place the text, the story, the discourse, the images into the thinking body of the actor and into our own body. The consequence is that the spectator is not just decoding ready-made signs of the actor's body, but embodying herself the actor's embodiment. Everything embodies itself in the performing bodies, even - according to Brecht and Bourdieu - power and capital. For instance, according to Brecht, the Gestus of the actor reveals a class attitude, a relation of power, a physical and social attitude. Try to find out, as author or reader, "[...] what scripts assume about actors' bodies", try to "[...] see how the dialogue text assumes, and scripts, a particular sort of bodily action" (Wallis; Shepherd, 2012, p. 112-113).

4) Examples of embodiment in the actor or in the mise en scène are: the figure, the trajectory (trajectoire): the actors draw in space and time their stage blocking, their movements and their attitudes. Trajet de l'inconscient: trajectory of the actor on stage, trajectory of the unconscious, as Vitez used to say. There is always a kinaesthetic acting and staging: how the actor moves, how the director directs her actors, how the spectator receives the moving body of the actor is a matter of kinaesthetic empathy. Sometimes the mise en scène is purely physical and choreographic (for instance, Passim, by F. Tanguy or The Trial and Three sisters, by Kriegenburg).

For playwrights: Even for a psychological drama, the bodies, their places, their displacements, moves must be taken into account. 
In writing your text, think spatially, visually, bodily, kinaesthetically, and then place your text into this structure.

\section{Beyond the Classical Western Actor}

Avatars of the Actor

1) The cyborg, as an anti-star and a reliable actor, is already used in some performances. Oriza Hirata chooses a cyborg for the third of the three sisters in Chekhov's play. See Bianca Li's choreography: Robot (2015).

2) The activist: uses theatre and acting as tools for a political or ecological cause. The actor is a facilitator, using techniques of the theatre to dramatize and theatricalize an issue.

3) The actor in the public sphere (Öffentlichkeit): not only in the theatre building. The actor/performer appears in different social contexts. If the framework and the coordinates of the theatre are dissolved, the actor also loses her artistic and professional identity.

For playwrights: Acting and also playwriting, staging etc. is not, should not be a formal, self-contained game. Playwriting always stays in contact with our real world; we cannot ignore it, and we should get inspiration from it.

\section{Rethinking the Actor's Body and Spirit Interculturally}

1) We should not impose another cultural model (like the Japanese model of Zeami) (La tradition secrete $d u$ nô. Paris, Gallimard, 1960) on the different Western models. But we should profit from these non-European models to check and discuss our Western categories. For example, we can confront and adapt Zeami's use of the metaphor bone/flesh/skin, which he used to describe the qualities of a good Noh actor:

a) I call bone the innate ground and manifestation of inspired power, giving rise to ability (Spirit). Does the acting make sense and does it make the work of art be understood in an original way?

b) I call flesh: the appearance of perfect style, which gets its strength in the study of dance and singing (Hearing). Does the acting sound right, as music can sound right, harmonious, pleasing? 
c) I call skin an interpretation which, while developing these elements, reaches the summit of easiness and beauty (Sight). Is this acting pleasant to watch aesthetically (harmony, proportions, balance)?

Robert Wilson (not referring explicitly to Zeami) uses the same metaphor to illustrate his working method, but in order to make another point: "I start with the surface of the work and here lies all mystery. What is behind the surface is something else. Skin, flesh and bones: this is a classical way of structuring time and space (Wilson, 2014, n. p.)".

For Wilson: the space, the shapes, the light are the external elements which he first decides on; he then puts the actors into the frame, and at the very end he sets the text: according to him, the most internal element.

I would myself suggest to use this distinction to plead for a continuum between: bone (abstraction of geometrical forms, of mechanisms, or compact narrative), then flesh (animal, improvisation, wild naturalism), then skin (details of critical realism, human touches and nuances).

For playwrights: your acting - but also your writing - should try to locate itself within the scope or spectrum abstract/concrete, or deep/superficial, or invisible/visible.

2) A globalized actor? Does globalization lead to a globalized actor (and thus to a globalized performance), an actor adaptable to all kinds of cultural contexts? Or adaptable to all kinds of international festivals (festival compatible)?

A commodified actor, whose costumes, but also facial expressions, attitudes, tics, love stories etc. can be sold on line during the performance, as this already happens for the cinema.

Yes, maybe, but we also witness an international, cosmopolitan reaction against the commodification of the actor: a resistance which is at the same time aesthetic and political.

What would be a cosmopolitan, or cosmopolitical, actor? It would be an actor able to act in different kinds of productions and cultural contexts (Dream of Peter Brook and Mnouchkine and presently of Lepage). In other cultural, foreign contexts, the acting techniques are not psychological, but physical. These techniques are a discovery and not necessarily a robbery for the Western actor. 


\section{Conclusions on the Actor}

1) De-dramatize the role of the actor: it is only a part of the theatre performance: it takes its meaning from the whole performance, both from the point of view of the production (as a semiotic structure) and from the point of view of reception (as a construction through the spectator's viewpoint).

2) Localizeldelocalize the actor? Is she the source and origin of all that result from her identity (localization and centring)? In that case, we will not be really surprised by what she does: it will seem only an illustration, a repetition of the already known. Or is the actor the result of the whole use of space, time, light, rhythm which provide her framework (delocalization and decentring).

For playwrights: consider first what the character/actor can do in a certain (psychologically and socially motivated) situation or in an (abstract) apparatus (dispositif). Affects - not signs or emotions - produce intensities, but they need a disposition, a disponibilité (availability), a dispositive - in short: an apparatus - to allow the energy to circulate. Thus the text or the work of art, the theatrical performance become an installation, thus a spatial configuration, not an essence or a coherence. This installation becomes itself an apparatus (dispositif), where the material and the conceptual merge.

3) Empty/refill the actor? The contemporary actor (performer) is an empty crossroad which must be constantly filled with, or emptied from, all sorts of identities and tasks to be fulfilled. Her main task is no longer only psychological or even only psycho-physical. It is aesthetic, anthropological and political.

For playwrights: the text is an empty construction which one first has to empty (no prejudice, no preconceived idea), and immediately after to fill or refill with a possible interpretation. Every new interpretation and acting performance fills the gaps. The identity of the character is not only psychological or psycho-physical; it entails a certain aesthetic attitude, an anthropological hypothesis, a political debate and discussion.

4) Train/un-train the actor? The training, however hard and ethical it may be, is not an end in itself. It must be reconsidered, rethought and probably reformed.

A few final recommendations: 
a) The training should not be solely physical or solely psychological.

b) The training should be, above all, a political, philosophical, critical, even sentimental education: an "ästhetische Erziehung" (Schiller, 1795), an aesthetic education.

c) We should STOP looking for the perfect actor, the overspecialized, over-trained, over-drilled, over-technical, übermenschlich actor.

For playwrights: never mind a lack of technical acting skills, if you can offer an abundance of interpretative propositions and invent new ways of doing theatre.

d) We should START looking for a productive, practical, adaptable, political actor, an artist helping the spectator to find some orientation within oneself and within the world.

For playwrights: playwriting (creating, doing art) is always a way to reconsider your position in the world. Make use of new forms, techniques, trajectories which can help you relocate yourself. Always reallocate yourself a task and a project for what you are doing, taking the outside world necessarily into consideration and becoming thus the spectator of the author/actor you are trying to be. 


\section{Notes}

${ }^{1}$ Introduction to the conference, organized by Ramuné Baleviciuté, Lithuanian Academy of Music and Theatre, October 2014, Vilnius, Lithuania.

2 "Actually incorporation contains three meanings: it means to obtain pleasure by making an object penetrate oneself; it means to destroy this object; and it means, by keeping it within oneself, to appropriate the object's qualities. It is this last aspect which makes incorporation into the matrix of introjection and identification" (Chemama; Vandermersch, 1998, p. 191).

\section{References}

BACHELARD, Gaston. La Terre et les Rêveries de la Volonté. Paris: Corti, 1948.

BUTLER, Judith. Gender Trouble: feminism and the subversion of identity. London: Routledge, 2006.

CHEMAMA, Roland; VANDERMERSCH, Bernard. Dictionnaire de la Psychanalyse. Paris: Larousse, 1998.

REYNOLDS, Dee. Kinestetic Empathy in Creative and Cultural Practice. Bristol: Intellect Books, 2012.

SCHILLER, Friedrich. Ueber die ästhetische Erziehung des Menschen, in einer Reihe von Briefen. 1795.

WALLIS, Mike; SHEPHERD, Simon. Studying Plays. London: Hodder Education, 2002. WILSON, Robert. Programme du Spectacle The Old Woman. Paris: Théâtre de la Ville, 2014.

Patrice Pavis is currently professor in the School of Arts at the University of Kent at Canterbury. He has published a Dictionary of Theatre and books on semiology, performance analysis, contemporary French dramatists, and contemporary theatre. His most recent book publications are La mise en scène contemporaine (Armand Colin, 2007; English translation, Routledge, 2013) and Dictionnaire de la performance et du théâtre contemporain (Armand Colin, 2014; English translation, Routledge, 2016). E-mail: patricepavis@hotmail.com

This unpublished text, proofread by Ananyr Porto Fajardo, is also published in Portuguese in this issue. 